Andrzej Szewc ${ }^{1}$

\title{
PRZESTĘPSTWA I WYKROCZENIA PRZECIWKO PRAWOM WŁASNOŚCI PRZEMYSŁOWEJ
}

\section{Uwagi ogólne}

Główną metodą ochrony własności intelektualnej jest metoda cywilnoprawna polegająca na stosowaniu takich narzędzi prawnych, jak roszczenie o zaniechanie naruszeń, naprawienie szkody, wydanie bezpodstawnie uzyskanych korzyści itp. ${ }^{2}$ W pewnym zakresie stosuje się jednak także inne metody prawne, w tym metodę karnoprawną. ${ }^{3}$ Po metodę tę sięgnął również ustawodawca polski zamieszczając w ustawach normujących ochronę tej własności przepisy karne. W ustawie z dnia 30 czerwca 2000 r. Prawo własności przemysłowej jest to tytuł X, zatytułowany „Przepisy karne", obejmujący art. 303-310 tej ustawy, w ustawie dnia 4 lutego 1994 r. o prawie autorskim i prawach pokrewnych ${ }^{5}$ - rozdział 14., zatytułowany „Odpowiedzialność karna" (art. 115-123), a w ustawie dnia 16 kwietnia 1993 r. o zwalczaniu nieuczciwej konkurencji - rozdział 4 ,Przepisy karne” (art. 23-27 u.z.n.k.). ${ }^{6}$

1 Doktor habilitowany, profesor Politechniki Świętokrzyskiej.

$2 \quad$ Z najnowszych opracowań zob. P. Podrecki, Środki ochrony praw własności intelektualnej, Warszawa 2010; E. Traple, Naruszenie patentu, (w:) R. Skubisz (red.), System Prawa Prywatnego, t. 14a, Prawo własności przemysłowej, Warszawa 2012, s. 737 i n.; K. Szczepanowska-Kozłowska, Naruszenie praw własności przemysłowej, (w:) E. Nowińska (red.), K. Szczepanowska-Kozłowska (red.), System Prawa Handlowego, t. 3, Prawo własności przemysłowej, Warszawa 2015, s. 667 i n. (dalej: SPH, t.3).

3 Z prac treści ogólnej zob. zwłaszcza Z. Ćwiąkalski, Odpowiedzialność karna, (w:) J. Barta (red.), M. Czajkowska-Dąbrowska, Z. Ćwiąkalski, R. Markiewicz (red.), E. Traple, Komentarz do ustawy o prawie autorskim i prawach pokrewnych, Warszawa 1995, s.472 i n.; idem, Wybrane zagadnienia ochrony prawno-karnej w prawie autorskim i prawie własności przemysłowej, (w:) T. Szymanek (red.), Naruszenia praw na dobrach niematerialnych, Warszawa 2001, s. 367 i n.

$4 \quad$ Tekst jedn. Dz.U. z 2013 r. poz. 1410; dalej: p.w.p.

$5 \quad$ Tekst jedn. Dz.U. z 2006 r. Nr 90, poz. 631 z późn. zm.; dalej: pr. aut. Zob. art. 115 i n. tej ustawy.

$6 \quad$ Tekst jedn. Dz.U. z 2003 r. Nr 153, poz. 1503 z późn. zm.; dalej w skrócie - u.z.n.k. Z uwagi na ograniczone ramy artykułu oraz odmienny od systemu ochrony patentowej i autorsko-prawnej, system zwalczania nieuczciwej konkurencji, oparty na zasadzie ochrony deliktowej, a nie na konstrukcji wyłącznych praw podmiotowych, w dalszych wywodach pominięto przepisy u.z.n.k., tym bardziej że z znacznym stopniu pozostaje tu aktualne wcześniejsze piśmiennictwo dotyczące tej materii - zob. M. Mozgawa, (w:) J. Szwaja (red.), Ustawa o zwalczaniu nieuczciwej konkurencji, Komentarz, Warszawa 2000, s. 593 i n. oraz A. Szewc, Naruszenie własności przemysłowej, Warszawa 2003, s. 105 i n. i powołane tam piśmiennictwo. Z nowszych publikacji zob. zwłaszcza M. Zdyb (red.), 
Są to w większości przepisy materialne, określające czyny zabronione pod groźbą kary w zakresie własności intelektualnej oraz sankcje karne grożące za ich popełnienie. W sprawach, których w przepisach nie unormowano, stosuje się ustawę z dnia 6 czerwca 1997 r. Kodeks karny ${ }^{7}$ oraz ustawę z dnia 20 maja 1971 r. Kodeks wykroczeń, ${ }^{8}$ a w zakresie procedury orzekania o winie i karze - przepisy o postępowaniu karnym ${ }^{9}$ lub (w przypadku czynów będących wykroczeniami) o postępowaniu w sprawach wykroczeń. ${ }^{10}$

\section{Ogólna charakterystyka czynów zabronionych przez p.w.p. ${ }^{11}$}

Czynami zabronionymi przez p.w.p. są:

- naruszenie praw osobistych twórcy projektu wynalazczego (art. 303);

- naruszenie cudzego prawa do uzyskania tytułu ochronnego na projekt wynalazczy (art. 304);

- używanie podrobionych znaków towarowych (art. 305-306);

- wprowadzanie w błąd co do istnienia ochrony prawnej (art. 307 i 308).

Czyny te są w większości występkami. ${ }^{12}$ Jedynie czyny polegające na wprowadzaniu w błąd co do istnienia ochrony prawnej są wykroczeniami. Żaden z nich nie jest zbrodnią, tj. przestępstwem, za którego popełnienie grozi co najmniej kara pozbawienia wolności na czas nie krótszy niż 3 lata (art. 7 § 2 k.k.).

Za popełnienie tych czynów odpowiada się tylko w razie winy umyślnej, tj. po wykazaniu, że sprawca miał zamiar popełnienia tego czynu (dolus directus) albo przewidując możliwość jego popełnienia, na to się godził (dolus eventualis). $\mathrm{Z}$ winy nieumyślnej, polegającej na popełnieniu czynu bez zamiaru jego popełnienia, na skutek niezachowania ostrożności wymaganej w danych okolicznościach (tj. na skutek lekkomyślności lub niedbalstwa), odpowiada się tylko w przypadku naruszenia cudzego prawa do uzyskania tytułu ochronnego określonego w art. 304 ust. 3 p.w.p. oraz w wypadku popełnienia wykroczenia, chyba że ustawa ogranicza odpowiedzialność za wykroczenie tylko do winy umyślnej (zob. art. 5 k.w.).

A. Michalak, M. Mioduszewski, J. Raglewski, J. Rasiewicz, M. Sieradzka, J. Sroczyński, M. Szydło, M. Wyrwiński, Ustawa o zwalczaniu nieuczciwej konkurencji. Komentarz, LEX 2011, objaśnienia do art. 23 i n. u.z.n.k.

Dz.U. z 1997 r. Nr 88, poz. 553 z późn. zm., dalej: k.k.

Tekst jedn. Dz.U. z 2013 r. poz. 482 z późn. zm., dalej: k.w.

Ustawa z dnia 6 czerwca 1997 r. Kodeks postępowania karnego (Dz.U. Nr 89, poz. 555 z późn. zm.).

Ustawa z dnia 24 sierpnia 2001 r.- Kodeks postępowania w sprawach o wykroczenia (tekst jedn. Dz.U. z 2013 r. poz. 395 z późn. zm.).

11 Zob. też S. Tosza, W. Wróbel, (w:) Prawo własności przemysłowej. Komentarz, 2. wydanie, Warszawa 2014, s. 1432 in.

12 Występkami nazywa się czyny zabronione zagrożone grzywną powyżej 30 stawek dziennych, karą ograniczenia wolności albo karą pozbawienia wolności przekraczającą miesiąc (art. 7 § 3 k.k.). Czyny zagrożone karami niższymi są wykroczeniami. 
Niektóre z omawianych czynów występują w podwójnej, a nawet potrójnej postaci: zwykłej (standardowej), uprzywilejowanej (karanej lżej) i kwalifikowanej (karanej surowiej). Okolicznościami zaostrzającymi odpowiedzialność karną są: działanie w celu osiągnięcia korzyści majątkowej lub osobistej (art. 303 ust. 2 p.w.p.), uczynienie sobie z popełnienia czynu stałego źródła dochodu oraz dopuszczenie się przestępstwa w stosunku do towaru o znacznej wartości (art. 305 ust. 3). Okolicznością łagodzącą odpowiedzialność sprawcy jest ,przypadek mniejszej wagi" (art. 305 ust. 2 p.w.p.).

Większość czynów określonych w tytule X p.w.p. to tzw. przestępstwa i wykroczenia kierunkowe - znamienne celem, motywem lub pobudką działania sprawcy, na przykład chęcią osiągnięcia korzyści majątkowej lub osobistej lub celem wprowadzenia towarów do obrotu.

Określone w omawianym tytule p.w.p. czyny można klasyfikować także z punktu widzenia podziału przestępstw i wykroczeń na przestępstwa (wykroczenia) skutkowe (inaczej: materialne) i bezskutkowe (inaczej: formalne). ${ }^{13}$

Cechą przestępstw materialnych jest włączenie skutku czynu do ustawowych znamion przestępstwa. Inaczej mówiąc, dopiero wystąpienie skutku powoduje, że czyn staje się przestępstwem w ogóle lub przestępstwem danego rodzaju. Nie ma zabójstwa dopóty, dopóki ofiara nie zostanie pozbawiona życia (wcześniejsze działania można kwalifikować jedynie jako naruszenie nietykalności cielesnej, uszkodzenie ciała, spowodowanie rozstroju zdrowia, a nawet usiłowanie zabójstwa); nie ma przestępstwa naruszenia tajemnicy państwowej lub służbowej dopóty, dopóki wiadomość tajna lub poufna nie zostanie przekazana osobie niepowołanej do jej uzyskania itp. Pojęcie skutku rozumiane jest przy tym szeroko. „Jest to zmiana w świecie zewnętrznym, która może mieć różny charakter, i która da się oddzielić od samego zachowania się. Zmianą taką jest uszkodzenie rzeczy (art. 288 k.k.), uszczerbek na zdrowiu (art. 156 k.k.), pożar (art. 163 k.k.), ale również bezpośrednie niebezpieczeństwo dla życia (art. 160 k.k.), pozbawienie człowieka wolności (art. 189 k.k.) lub obawa (art. 190)"'.14

Dla przestępstw formalnych wystąpienie skutku czynu jest prawnie obojętne; liczy się wyłącznie zachowanie sprawcy spełniające ustawowe znamiona, na przykład nakłanianie do uprawiania nierządu lub do składania fałszywych zeznań, składanie takich zeznań, podżeganie do popełnienia przestępstwa itp. Przestępstwo nakłaniania (podżegania) jest popełnione niezależnie od tego, czy osoba nakłaniana do uprawiania nierządu lub do popełnienia przestępstwa dała się do tego przekonać, zaś za składanie fałszywych zeznań odpowiada się także wtedy, gdy sąd nie dał im wiary.

Czyny, o których expressis verbis mówią przepisy art. 303-310 p.w.p., to w zdecydowanej większości przestępstwa (wykroczenia) formalne, dla ich popełnienia

\footnotetext{
13 Zob. bliżej K. Buchała, Prawo karne materialne, Warszawa, 1989, s. 155-156; A. Marek, Prawo karne. Część ogólna, wydanie drugie poprawione i uzupełnione, Warszawa 1993, s. 113 i n.

14 L. Gardocki, Prawo karne, 6. wydanie, Warszawa 2000, s. 57.
} 
nie jest bowiem konieczne zaistnienie takiej zmiany w świecie zewnętrznym, która da się oddzielić od samego zachowania się sprawcy. Na przykład przypisywanie sobie autorstwa cudzego projektu wynalazczego (plagiat), czy zgłoszenie cudzego projektu wynalazczego w UP przez osobę, która nie jest do tego uprawniona, jest przestępstwem niezależnie od tego, czy sprawca czynu osiągnie zamierzony skutek - a więc, czy otrzyma patent na cudzy wynalazek, zgłoszony na swoją rzecz. Podobnie ma się rzecz z wprowadzaniem do obrotu przedmiotów niechronionych prawami wyłącznymi napisami lub rysunkami mającymi wywołać mylne mniemanie, że przedmioty te korzystają $\mathrm{z}$ ochrony prawnej - przestępstwo zostaje popełnione $\mathrm{z}$ chwilą wprowadzenia tak oznaczonych wyrobów do obrotu, niezależnie od tego czy w wyniku tego doszło do konfuzji wśród nabywców.

Przestępstwami skutkowymi są jedynie:

- wprowadzenie innej osoby w błąd co do autorstwa cudzego projektu wynalazczego (art. 303 ust. 1 p.w.p.);

- uniemożliwienie osobie uprawnionej uzyskania patentu, prawa ochronnego lub prawa z rejestracji, np. poprzez ujawnienie uzyskanej informacji o cudzym wynalazku, wzorze użytkowym, wzorze przemysłowym albo cudzej topografii układu scalonego.

Nie można wykluczyć, że charakter przestępstw skutkowych mogą mieć także niektóre przestępstwa polegające na naruszeniu praw twórcy projektu wynalazczego „W inny sposób” niż sposoby opisane w art. 303 ust. 1 p.w.p.

Przestępstwa opisane w tytule X p.w.p. są ścigane z oskarżenia publicznego. Znamienną cechą większości tych czynów jest jednak ich wnioskowy charakter. Stosownie bowiem do art. 310 ust. 1 p.w.p., ściganie ich sprawców odbywa się ,,na wniosek pokrzywdzonego". Jedynie przestępstwo z art. 305 ust. 3 ścigane jest z urzędu.

Karami za przestępstwa przeciwko własności przemysłowej są: grzywna, kara ograniczenia wolności albo kara pozbawienia wolności.

Grzywna jest karą majątkową; polega na obowiązku zapłaty przez skazanego na rzecz Skarbu Państwa orzeczonej przez sąd sumy pieniężnej. Wedle art. $33 \S 1$ k.k. grzywnę wymierza się w tzw. stawkach dziennych, określając liczbę stawek oraz wysokość jednej stawki. Jeżeli ustawa nie stanowi inaczej, najniższa liczba stawek wynosi 10, zaś najwyższa 540. Jednakże przy nadzwyczajnym obostrzeniu kary (możliwym na przykład wtedy, gdy sprawca uczynił sobie z przestępstwa stałe źródło dochodu lub w razie recydywy) sąd może orzec grzywnę w wysokości 810 stawek (art. 38 § 2 k.k.). Ustalając stawkę dzienną, sąd bierze pod uwagę dochody sprawcy, jego warunki osobiste, rodzinne, stosunki majątkowe i możliwości zarobkowe; stawka dzienna nie może być niższa od 10 złotych, ani też przekraczać 2.000 złotych (art. $33 \S 3$ k.k.).

Grzywna jest zasadniczo karą samoistną. Może jednak być także karą akcesoryjną (orzekaną obok kary pozbawienia wolności), jeżeli sprawca dopuścił się czynu 
w celu osiągnięcia korzyści majątkowej lub gdy korzyść majątkową osiągnął (art. 33 $\S 2$ k.k.).

Kara ograniczenia wolności polega na tym, iż w czasie odbywania tej kary skazany nie może bez zgody sądu zmieniać miejsca stałego pobytu i jest obowiązany do wykonywania pracy wskazanej przez sąd; ma też obowiązek udzielania wyjaśnień dotyczących przebiegu odbywania kary (art. $34 \S 2$ k.k.). Obowiązek wykonywania pracy polega na wykonywaniu wskazanej przez sąd, nieodpłatnej, kontrolowanej pracy na cele społeczne $\mathrm{w}$ odpowiednim zakładzie pracy, placówce służby zdrowia, opieki społecznej, organizacji lub instytucji niosącej pomoc charytatywną lub na rzecz społeczności lokalnej, w wymiarze od 20 do 40 godzin w stosunku miesięcznym (art. $35 \S 1$ k.k.).

W stosunku do osoby zatrudnionej można - zamiast obowiązku wykonywania pracy - orzec potrącenie od 10 do $25 \%$ wynagrodzenia za pracę na rzecz Skarbu Państwa albo na cel społeczny wskazany przez sąd, przy czym w okresie odbywania kary skazany nie może rozwiązać bez zgody sądu stosunku pracy (art. $35 \S 2$ k.k.).

Jeżeli ustawa nie stanowi inaczej, kara ograniczenia wolności trwa najkrócej miesiąc, najdłużej 12 miesięcy; wymierza się ją w miesiącach (art. 34 § 1 k.k.).

Wymierzając karę ograniczenia wolności, sąd może nadto zobowiązać skazanego do:

- przeproszenia pokrzywdzonego,

- wykonywania ciążącego na skazanym obowiązku łożenia na utrzymanie innej osoby,

- powstrzymania się od nadużywania alkoholu lub używania innych środków odurzających,

- naprawienia w całości albo w części szkody wyrządzonej przestępstwem (art. $36 \S 2$.$) .$

Karę pozbawienia wolności wymierza się w miesiącach i latach; minimum kary pozbawienia wolności wynosi 1 miesiąc, maksimum - 15 lat. (art. 37 k.k.).

$\mathrm{Z}$ uwagi na to, że górna granica kary pozbawienia wolności przewidziana za przestępstwa określone w PWP nie przekracza 5 lat, sąd może w każdym przypadku orzec zamiennie grzywnę albo karę ograniczenia wolności (art. 58 § 3 k.k.). Przepisu tego nie stosuje się jednakże wobec sprawcy występku o charakterze chuligańskim oraz wobec sprawcy, o którym mowa w art. 178a kk. (art. 58 § k.k.).

Karami za wykroczenia są:

- areszt,

- ograniczenie wolności,

- grzywna,

- nagana (art. 19 k.w.). 
Kara aresztu trwa najkrócej 5, najdłużej 30 dni; wymierza się ją w dniach. Kara ograniczenia wolności, identyczna z karą unormowaną w kodeksie karnym, trwa 1 miesiąc. Wymierzając tę karę, organ orzekający może zobowiązać ukaranego do:

- naprawienia w całości albo w części szkody wyrządzonej wykroczeniem,

- przeproszenia pokrzywdzonego.

Jeżeli ukarany uchyla się od wykonywania kary ograniczenia wolności, ulega ona zamianie na zastępczą karę grzywny, przy czym miesiąc ograniczenia wolności przyjmuje się za równoważny grzywnie od 75 do 2.250 złotych, a jeżeli okoliczności wskazują na to, że egzekucja grzywny nie będzie skuteczna - na zastępczą karę aresztu, przy czym miesiąc ograniczenia wolności odpowiada 15 dniom aresztu.

Grzywna za wykroczenia jest grzywną ryczałtową; wymierza się ją w wysokości od 20 do 5.000 złotych, chyba że ustawa stanowi inaczej. Jeżeli za wykroczenie popełnione w celu osiągnięcia korzyści majątkowej wymierzono karę aresztu, orzeka się obok tej kary również grzywnę, chyba że orzeczenie grzywny nie byłoby celowe. Wymierzając grzywnę, bierze się pod uwagę dochody sprawcy, jego warunki osobiste i rodzinne, stosunki majątkowe i możliwości zarobkowe.

Oprócz - a niekiedy zamiast - kary sąd może orzec środki karne (art. 39 i n. k.k. oraz art. 28 k.w.). ${ }^{15} \mathrm{~W}$ szczególności, w odniesieniu do omawianych spraw znaczenie mogą mieć takie środki karne, jak: zakaz prowadzenia określonej działalności gospodarczej, przepadek przedmiotów, obowiązek naprawienia szkody, nawiązka, świadczenie pieniężne, o którym mowa w art. 49 k.k. oraz podanie orzeczenia o ukaraniu do publicznej wiadomości w szczególny sposób. W związku z tym podkreślić należy, że wedle art. 306 ust. 1 p.w.p. w razie skazania za przestępstwo określone w art. 305 ust. 3 sąd obligatoryjnie orzeka przepadek na rzecz Skarbu Państwa towarów pochodzących z przestępstwa oraz materiałów i narzędzi, jak również środków technicznych, które służyły lub były przeznaczone do popełnienia przestępstwa; jeżeli takie materiały, narzędzia albo środki techniczne nie były własnością sprawcy, sąd może orzec ich przepadek na rzecz Skarbu Państwa, a w razie skazania za przestępstwo określone w art. 305 ust. 1 i 2 p.w.p. - może orzec ich przepadek na rzecz Skarbu Państwa nawet wtedy, gdy nie są one własnością sprawcy (art.306 ust. 2 p.w.p.).

W piśmiennictwie podniesiono również, że „szczególnym środkiem karnym, nie wymienionym jednak w art. 39 k.k. jest nałożenie obowiązku zwrotu korzyści majątkowych (w całości lub w części) odniesionych z przestępstwa. Chodzi o sytuację, gdy w wyniku przestępstwa sprawcy inna osoba fizyczna lub prawna albo jednostka organizacyjna nie posiadająca osobowości prawnej odniosła korzyść ma-

Zwane dawniej „karami dodatkowymi”. 
jątkową kosztem Skarbu Państwa, sprawca działał zaś w imieniu lub w interesie tych podmiotów". 16

\section{Przestępstwa przeciwko prawom twórcy projektu wynalazczego (art. 303 p.w.p.)}

Należą tutaj:

- przypisywanie sobie autorstwa cudzego projektu wynalazczego,

- wprowadzenie w błąd innej osoby co do autorstwa projektu wynalazczego,

- naruszenie praw twórcy projektu w inny sposób.

Pojęcie praw twórcy zdefiniowano w art. 8 p.w.p. Obejmują one prawo do autorstwa (które - jako prawo osobiste - przysługuje zawsze twórcy projektu) ${ }^{17}$ oraz prawa majątkowe (jak np. prawo do uzyskania patentu), które - jako prawo majątkowe - może przysługiwać również innym podmiotom, w tym następcom prawnym twórcy. ${ }^{18} \mathrm{~W}$ tym ostatnim przypadku sankcje karne za naruszenie praw twórcy przewidziane w art. 303 p.w.p. - zgodnie z zasadą nullum crimen sine lege - będą miały zastosowanie tylko wówczas, gdy podmiotem tych praw będzie twórca projektu wynalazczego.

Przypisywanie sobie autorstwa cudzego projektu wynalazczego, czyli tzw. plagiat, polega na bezpodstawnym podawaniu się za twórcę lub współtwórcę projektu. ${ }^{19}$ Przedmiotem ochrony jest autorstwo projektu wynalazczego, czyli okoliczność faktyczna polegająca na dokonaniu projektu i związane z tym „ojcostwo” projektu. Nie należy go mylić z dobrem osobistym, jakim jest rezultat twórczości wynalazczej lub racjonalizatorskiej (zob. art. 23 k.c.).

Omawiane przestępstwo jest przestępstwem z działania, ale formalnym, jego karalność nie zależy bowiem od tego, czy osoby trzecie, wobec których sprawca podaje się za twórcę lub współtwórcę projektu, uwierzą w tę okoliczność, czy nie. Popełnić je można tylko z winy umyślnej w zamiarze bezpośrednim.

Wprowadzenie w błąd innej osoby co do autorstwa projektu wynalazczego jest - podobnie jak plagiat - przestępstwem umyślnym, z tym że popełnić je można także

\footnotetext{
16 J. Wojciechowska, (w:) G. Rejman (red.), Kodeks karny. Część ogólna. Komentarz, Warszawa 1999, s. 881.

17 Bliżej na ten temat zob. A. Kubiak-Cyrul, J. Szwaja, Twórcy i ich prawa osobiste, (w:) R. Skubisz (red.), System Prawa Prywatnego, t. 14a, Prawo własności przemysłowej, Warszawa 2012, s. 343 i n.

18 Prawa majątkowe własności przemysłowej są zbywalne i podlegają dziedziczeniu - zob. art. 17 ust. 1 i art. 67 ust. 1 p.w.p.

19 E. Czepita, Prawnokarna ochrona autorstwa projektu na podstawie art. 116 ustawy o wynalazczości, „Prace Naukowe Uniwersytetu Śląskiego” nr 257, seria: Problemy Prawa Wynalazczego i Patentowego, t. 4, M. Staszków (red.), Katowice 1978, s.71 i n.; A. Szewc, Plagiat, „Monitor Prawniczy” 1996, nr 2, s. 43-46, a z nowszej literatury J. Sieńczyło-Chlabicz, Odpowiedzialność nauczycieli akademickich, doktorantów i studentów z tytułu popełnienia plagiatu, „Transformacje Prawa Prywatnego” 2010, nr 1; J. Sieńczyło-Chlabicz, J. Banasiuk, Pojęcie i istota zjawiska autoplagiatu w twórczości naukowej, „Państwo i Prawo” 2012, z. 3; S. Stanisławska-Kloc, Plagiat contra autoplagiat, (w:) A. Matlak, S. Stanisławska-Kloc (red.), Spory o własność intelektualną, LEX, s. 1091 i n.; eadem, Plagiat - zagrożenie dla autorstwa w XXI w., (w:) J Balcarczyk (red.), Dobra osobiste w XXI wieku. Nowe wartości, zasady, technologie, Warszawa 2012, s. 313 i n.
} 
W zamiarze ewentualnym. W przeciwieństwie do plagiatu jest ono przestępstwem materialnym (skutkowym), polega bowiem na wprowadzeniu (a nie - wprowadzaniu) innej osoby w błąd co do tego, kto jest autorem (twórcą) projektu wynalazczego. Od plagiatu różni je także to, że może być popełnione przez zaniechanie.

Naruszenie praw twórcy projektu w inny sposób polegać będzie na takim wkroczeniu w sferę praw podmiotowych twórcy, które nie wyraża się w czynach expressis verbis opisanych w art. 303 ust. 1 i 304 p.w.p. Będzie to na przykład naruszenie prawa twórcy do wynagrodzenia za projekt wynalazczy przez bezzasadną odmowę przyznania lub wypłaty wynagrodzenia. Przestępstwo to jest przestępstwem umyślnym (w zamiarze bezpośrednim lub ewentualnym), które może przejawiać się jako przestępstwo z działania bądź zaniechania, skutkowe lub formalne.

Przestępstwa przeciwko prawom twórcy są zagrożone alternatywnie karami: grzywny, ograniczenia wolności albo pozbawienia wolności do roku bądź - przy kwalifikowanej postaci czynu, znamiennej tym, że sprawca działa w celu osiągnięcia korzyści majątkowej lub osobistej - do lat dwóch. Alternatywność zagrożenia i górny wymiar kary pozbawienia wolności powodują, że w przypadkach, w których społeczna szkodliwość czynu nie jest znaczna, sąd może odstąpić od wymierzenia kary i zastosować środek karny, ${ }^{20}$ jeżeli cele kary zostaną przez ten środek spełniony (art. 59 k.k.), jak również - w razie spełnienia przesłanek określonych w art. 69 k.k. - zawiesić wykonanie orzeczonej kary pozbawienia wolności. Z kolei kierunkowy charakter kwalifikowanej postaci tych przestępstw (działanie w celu osiągnięcia korzyści majątkowej) sprawia, iż sąd może w tych przypadkach wymierzyć, obok kary pozbawienia wolności, również grzywnę (art. 33 § 2 k.k.). ${ }^{21}$

Omawiane tutaj występki są przestępstwami wnioskowymi - ich ściganie następuje na wniosek pokrzywdzonego twórcy lub współtwórcy projektu wynalazczego (art. 310 ust. $1 \mathrm{w}$ zw. $\mathrm{z}$ art. 8 ust. 3 p.w.p.).

\section{Przestępstwa przeciwko prawu do uzyskania tytułu ochronnego}

Przestępstwa te - określone w art. 304 p.w.p. - obejmują trzy typy czynów:

- zgłoszenie cudzego projektu wynalazczego w UP w celu uzyskania prawa wyłącznego (patentu, prawa ochronnego albo prawa z rejestracji),

- ujawnienie uzyskanej informacji o cudzym wynalazku, wzorze użytkowym, wzorze przemysłowym albo cudzej topografii,

- uniemożliwienie uzyskania prawa wyłącznego w inny sposób.

20

21 rzyść taką osiągnął. Nie daje natomiast podstawy do akcesoryjnego wymierzenia grzywny działanie w celu osiągnięcia lub osiągnięcie korzyści osobistej. 
Przestępstwa te mają wspólny przedmiot zamachu, tj. materialne uprawnienie innej osoby do uzyskania tytułu ochronnego na projekt wynalazczy. ${ }^{22} \mathrm{~W}$ pozostałych cechach się różnią. I tak:

- zgłoszenie cudzego projektu wynalazczego w UP jest przestępstwem z działania, kierunkowym (w celu uzyskania prawa wyłącznego) i formalnym (ustawowe znamiona tego czynu wyczerpuje już samo zgłoszenie cudzego projektu w UP, uzyskanie tytułu ochronnego nie jest konieczne);

- ujawnienie uzyskanej informacji o cudzym wynalazku, wzorze użytkowym, wzorze przemysłowym albo cudzej topografii można się dopuścić z działania lub zaniechania (np. przez nienależyte zabezpieczenie dokumentacji projektu przed dostępem osób niepowołanych). Przestępstwo to ma charakter skutkowy ponieważ zostaje popełnione dopiero wtedy, gdy ujawnienie informacji uniemożliwi osobie uprawnionej uzyskanie tytułu ochronnego (w szczególności w wyniku utraty zdolności patentowej, ochronnej lub rejestrowej); ${ }^{23}$

- uniemożliwienie uzyskania prawa wyłącznego w inny sposób może być rezultatem działania lub zaniechania (na przykład niezgłoszenia pracodawcy pracowniczego projektu wynalazczego w umówionym terminie, skutkiem czego inny podmiot wcześniej zgłosił do UP rozwiązanie pararelne), ale zawsze jest przestępstwem skutkowym.

W obrębie hipotezy występku polegającego na zgłoszeniu bez uprawnienia cudzego wynalazku w UP mieszczą się dwojakiego rodzaju sytuacje:

- gdy zgłaszający zgłasza cudzy wynalazek w celu uzyskania patentu na własną rzecz. Naruszenie prawa do patentu polega tu na przywłaszczeniu sobie cudzego prawa. Przywłaszczenie może dotyczyć tylko części prawa, stąd omawiane przestępstwo zachodzi również wtedy, gdy zgłaszający ubiega się o udzielenie mu patentu na cały wynalazek, gdy w istocie jest tylko jednym ze współuprawnionych do uzyskania tego tytułu;

- gdy zgłaszający zgłasza cudzy wynalazek w celu udzielenia patentu na rzecz osoby uprawnionej wbrew woli tej osoby. Naruszenie prawa do patentu będzie tu polegać na odebraniu osobie uprawnionej prawa do decydowania o formie ochrony wynalazku (ochrona prawna lub faktyczna) ${ }^{24}$ oraz jej zakresie - uniemożliwia jej bowiem uzyskanie ochrony w innym kształcie aniWarszawa 2011, s. 161 i n.; M. du Vall, Prawo do uzyskania patentu i jego ochrona, (w:) R. Skubisz (red.), System Prawa Prywatnego, t. 14a, Prawo własności przemysłowej, Warszawa 2012, s. 383 i n.

23 W sprawie tych zdolności zob. M. du Vall, Przesłanki zdolności patentowej, (w:) System Prawa Prywatnego, t. 14a, s. 308 i n.; idem, Przesłanki zdolności ochronnej [wzoru użytkowego], ibidem, s 830 i n.; A. Wojciechowska, A. Tischner, Przesłanki zdolności rejestrowej wzorów przemysłowych, (w:) R. Skubisz (red.), System Prawa Prywatnego, t. 14b, Prawo własności przemysłowej, Warszawa 2012, s. 68 i n.

24 Zagadnienia faktycznej i prawnej ochrony dóbr intelektualnych zostały ostatnio obszernie omówione przez J. Ożegalską-Trybalską i K. Szczepanowską-Kozłowską, M. Modrzejewską, A. Niewęgłowskiego i A. Szewca, 
żeli wynika to $\mathrm{z}$ dokonanego zgłoszenia. $\mathrm{Z}$ tego względu czyn taki można również kwalifikować jako występek $\mathrm{z}$ art. 304 ust. 2 p.w.p. polegający na uniemożliwieniu „w inny sposób” uzyskania patentu, prawa ochronnego lub prawa $\mathrm{z}$ rejestracji.

Przestępstwo ujawnienia informacji o cudzym projekcie wynalazczym może być popełnione zarówno z winy umyślnej (celowo), jak i z winy nieumyślnej, polegającej na tym, że ,sprawca nie mając zamiaru popełnienia czynu, popełnia go jednak na skutek niezachowania ostrożności wymaganej w danych okolicznościach, mimo że możliwość popełnienia tego czynu przewidywał albo mógł przewidzieć" (art. $9 \S 2$ k.k.). ${ }^{25} \mathrm{~W}$ tym drugim przypadku warunkiem odpowiedzialności sprawcy jest wymóg, aby był on zobowiązany do zachowania w tajemnicy uzyskanej informacji. Obowiązek ten może wynikać na przykład z przepisów o ochronie informacji niejawnych. Może to być jednak również obowiązek płynący ex contractu. Jest to jedyne przestępstwo nieumyślne przewidziane w p.w.p.

Sankcją za nieumyślne ujawnienie informacji o cudzym projekcie wynalazczym jest wyłącznie grzywna (art. 305 ust. 2 p.w.p.).

\section{Używanie podrobionych lub cudzych zarejestrowanych znaków towarowych (art. 305 p.w.p.)}

Występek opisany w art. 305 p.w.p. ma trzy formy modalne:

1) oznaczanie towarów podrobionym znakiem towarowym;

2) oznaczanie towarów zarejestrowanym znakiem towarowym, którego sprawca nie ma prawa używać;

3) dokonywanie obrotu towarami oznaczonymi takimi znakami.

Dwie pierwsze formy są przestępstwami kierunkowymi, znamionuje je bowiem cel przyświecający sprawcy - oznaczanie towarów wymienionymi znakami w celu wprowadzenia ich do obrotu. ${ }^{26} \mathrm{Nie}$ spełnia tego znamienia dokonywanie obrotu towarami oznaczonymi takimi znakami. ${ }^{27}$

Czyny sprawcy (oznaczanie towarów lub dokonywanie obrotu towarami oznaczonymi takimi znakami) polegają zawsze na działaniu. Można je popełnić tylko

(w:) K. Szczepanowska-Kozłowska, E. Nowińska (red.), System Prawa Handlowego t. 3, Prawo własności przemysłowej, Warszawa 2015, s. 233-352 i 499-666.

25 Praktycznie biorąc, przestępstwo nieumyślne popełnia się w wyniku lekkomyślności lub niedbalstwa.

26 Nie spełnia znamion tego przestępstwa oznaczanie towarów takimi znakami w innym celu niż wprowadzanie ich do obrotu.

27 W sprawie pojęć „wprowadzanie do obrotu” oraz „dokonywanie obrotu” zob. m.in. uchwałę (7) SN z dnia 30 czerwca 2008 r., I KZP 8/08 (OSNKW 2008/7/52), a także wyroki SN: z dnia 15 stycznia 2010 r., V KK 342/09 (LEX nr 570163); 19.04.2012 r., III KK 53/12 (LEX nr 1162703) i z dnia 23 maja 2013 r., III KK 91/13 (LEX nr 1318209). 
z winy umyślnej, zarówno w zamiarze bezpośrednim, jak i - przynajmniej w odniesieniu do trzeciej postaci modalnej - w zamiarze ewentualnym.

Przesłanką odpowiedzialności za pierwszy typ tego przestępstwa jest to, aby znak był „,podrobiony”. Przez taki znak rozumie się ,znak identyczny lub taki, który nie może być odróżniony w zwykłych warunkach obrotu od znaku zarejestrowanego, użyty bezprawnie dla towarów objętych prawem ochronnym" (art. 297 ust. 2 p.w.p.).

Omawiany występek jest zagrożony alternatywnie karami: grzywny, ograniczenia wolności albo pozbawienia wolności do lat dwóch (art. 305 ust. 1 p.w.p. Kary te wymierza się przy zwykłej (standardowej) odmianie czynu. Ustawa wyróżnia jednak dwie dalsze jego odmiany:

- uprzywilejowaną, zachodzącą „w wypadku mniejszej wagi” - sprawca podlega wówczas tylko grzywnie (art. 305 ust. 2);

- kwalifikowaną tym, że ,sprawca uczynił sobie z popełnienia przestępstwa określonego w ust. 1 stałe źródło dochodu albo dopuszcza się tego przestępstwa w stosunku do towaru o znacznej wartości” - grozi za nie wówczas kara pozbawienia wolności od 6 miesięcy do lat 5 (art. 305 ust. 3).

Ustawa nie precyzuje, co oznacza określenie ,towar znacznej wartości”. Moim zdaniem, należy je rozumieć analogicznie jak ,mienie znacznej wartości”, którym - zgodnie z art. $115 \S 5$ k.k. - jest ,mienie, którego wartość w chwili popełnienia czynu zabronionego przekracza dwustukrotną wysokość najniższego miesięcznego wynagrodzenia”, czyli „najniższego wynagrodzenia pracowników określonego na podstawie kodeksu pracy" (art. $115 \S 8$ k.k.). ${ }^{28}$ Wnioskując a minori ad maius można przyjąć, że z kwalifikowaną odmianą tego czynu będziemy - i to tym bardziej - mieć do czynienia wówczas, gdy przedmiotem przestępstwa jest „towar wielkiej wartości”, tj. taki, „którego wartość w chwili popełnienia czynu zabronionego przekracza tysiąckrotną wysokość najniższego miesięcznego wynagrodzenia" (art. 115 $\S 6$ k.k.).

Ze skazaniem za przestępstwo kwalifikowane (określone w art. 305 ust. 3 p.w.p.) wiąże się obowiązek orzeczenia przez sąd środka karnego w postaci przepadku na rzecz Skarbu Państwa towarów pochodzących z przestępstwa oraz materiałów i narzędzi, jak również środków technicznych, które służyły lub były przeznaczone do popełnienia przestępstwa albo możliwość orzeczenia takiego przepadku, jeżeli takie materiały, narzędzia albo środki techniczne nie były własnością sprawcy (art. 306 ust. 1 p.w.p.). Natomiast w razie skazania za przestępstwo standardowe (z art. 305 ust. 1 p.w.p.), sąd może orzec przepadek na rzecz Skarbu Państwa towarów pochodzących z przestępstwa oraz materiałów i narzędzi, jak również 
środków technicznych, które służyły lub były przeznaczone do popełnienia przestępstwa, chociażby nie były własnością sprawcy.

Stosownie do art. 187 i 188 ustawy z dnia 6 czerwca 1997 r. Kodeks karny wykonawczy ${ }^{29}$ wykonanie powyższego środka karnego polega na tym, że sąd bezzwłocznie po uprawomocnieniu się wyroku przesyła jego odpis lub wyciąg urzędowi skarbowemu, właściwemu ze względu na siedzibę sądu pierwszej instancji, w celu wykonania środka karnego przepadku przedmiotów lub ściągnięcia kwoty pieniężnej stanowiącej równowartość przedmiotów, których przepadku orzec nie było można. Na tej podstawie urząd skarbowy przejmuje w posiadanie składniki mienia wymienione w wyroku. Następnie przejęte nieruchomości przekazuje w zarząd właściwym organom administracji rządowej, a przejęte rzeczy ruchome, wierzytelności i inne prawa majątkowe spienięża według przepisów o egzekucji świadczeń pieniężnych w postępowaniu egzekucyjnym $\mathrm{w}$ administracji. ${ }^{30}$

Inny tryb postępowania stosuje się wówczas, gdy wartość przedmiotów, których przepadek orzeczono, jest nieznaczna; stosownie do art. 195 k.k.w. sąd pozostawia je w aktach sprawy albo zarządza ich zniszczenie.

W tej sytuacji przepis art. 306 ust. 3 p.w.p. nakazujący odpowiednie stosowanie art. 195 k.k.w. do każdego orzeczenia przepadku przedmiotów, o którym mowa w art. 306 ust. 1 i 2 p.w.p., i to „,niezależnie od wartości towarów, których przepadek orzeczono", wydaje się - oględnie mówiąc - zbyt radykalny i niespójny z zasadami prawa karnego wykonawczego.

\section{Wprowadzanie w błąd co do istnienia ochrony prawnej (art. 308 p.w.p.)}

Czyny, które tutaj należą, są wykroczeniami. Tak, jak się wydaje, należy rozumieć niezbyt fortunne wyrażenie, iż orzekanie w sprawach o te czyny „następuje w trybie przepisów o postępowaniu w sprawach o wykroczenia" (art. 310 ust. 2 p.w.p.). Nie jest bowiem możliwe, aby sąd rozpoznający sprawę karną stosował procedurę obowiązującą dla orzekania w sprawach wykroczeń. Cytowany przepis należy zatem rozumieć jako odsyłający in extenso do prawa wykroczeń, w tym także do prawa materialnego - kodeksu wykroczeń, a nie tylko do kodeksu postępowania w sprawach o wykroczenia.

Omawiane wykroczenia obejmują:

- oznaczanie przedmiotów niechronionych patentem, prawem ochronnym na wzór użytkowy albo prawem z rejestracji wzoru przemysłowego, topografii układu scalonego lub rejestracji na oznaczenie geograficzne, napisami

30 Tj. według art. 67 i nast. ustawy $z$ dnia 17 czerwca 1966 r. o postępowaniu egzekucyjnym w administracji (tekst jedn. Dz.U. z 2014 r. poz. 1619 z późn. zm.). 
lub rysunkami mającymi wywołać mylne mniemanie, że przedmioty te korzystają z takiej ochrony;

- wprowadzanie tak oznaczonych przedmiotów do obrotu;

- przygotowywanie tak oznaczonych przedmiotów do celów obrotu lub ich przechowywanie;

- podawanie w ogłoszeniach, zawiadomieniach lub w inny sposób wiadomości mających wywołać mniemanie, że te przedmioty korzystają z ochrony prawnej;

- wprowadzanie do obrotu towarów oznaczonych znakiem towarowym z wyróżnikiem $\left({ }^{\circledR}\right)$, mającym wywołać mylne mniemanie, że przedmioty te korzystają z takiej ochrony.

Wszystkie wymienione czyny są wykroczeniami formalnymi, nie jest bowiem konieczne wywołanie skutku w postaci wprowadzenia nabywców w błąd co do stanu ochrony prawnej tak oznaczonych przedmiotów. W przypadku zaistnienia takiego skutku i wyrządzenia $\mathrm{w}$ ten sposób istotnej szkody klientowi nastąpi zbieg tego wykroczenia $\mathrm{z}$ wykroczeniem przewidzianym w art. 25 u.z.n.k., warunkiem odpowiedzialności jest w tym wypadku jednak umyślne działanie sprawcy. W wypadku pozostałych wykroczeń sprawca odpowiada także za działanie nieumyślne (art. 5 k.w.).

Za popełnienie wymienionych wykroczeń grozi kara aresztu lub grzywna (art. 307 p.w.p., art. 25 u.z.n.k.) bądź też tylko grzywna (art. 308 p.w.p.). 


\section{OFFENCES AND MALFEASANCES AGAINST INDUSTRIAL PROPERTY RIGHTS}

The main method adopted for the protection of industrial property is civil liability, which uses claim litigation as the primary legal tool for addressing the exploitation of industrial property rightsand for recovering losses to the rights holder. However, in some cases the instruments of penal law are applied. In this respect the legislator saw fit to incorporate penal provisions on the violation of industrial property rightsin the Polish Patent Act.

This paper discusses the following offences and malfeasances against industrial property:

1) infringement of the moral rights of aninventor;

2) infringement of patent rights;

3) use of falsified trade-marks;

4) wilfully misleading third parties into believing in the existence of legal protection of an invention, utility model, etc.,

and the attendant principles of penal responsibility for committing such acts.

Słowa kluczowe: naruszenie własności przemysłowej, odpowiedzialność karna Keywords: violation of industrial property, penal responsibility 